\title{
Peningkatan profesionalitas layanan aparatur desa berbasis e-desa bagi pegawai kantor Desa Rimba Makmur
}

\author{
Nurjayadi*, Torkis Nasution, Herwin, \& Khusaeri Andesa \\ STMIK Amik Riau \\ *nurjayadi@stmik-amik-riau.ac.id
}

\begin{abstract}
Abstrak. Pentingnya kualitas bagi pegawai desa dalam pelaksanaan layanan dan pembangunan dari hasil penelitian menunjukan bahwa faktor sikap mental, faktor disiplin, faktor pendidikan bidang pelayanan akan turut menentukan pelaksanaan tugas bagi setiap pegawai pemerintah Desa. Pengabdian pada masyarakat ini bertujuan untuk meningkatkan kualitas pegawai serta penguasaan perangkat teknologi dan informasi pada pegawai Kantor Desa Rimba Makmur. Memberikan wawasan pengetahuan tentang pentingnya peningkatan profesionalitas dalam memberikan layanan terhadap masyarakat berbasis teknologi. Sasaran pengabdian adalah seluruh pegawai, dilanjutkan seluruh RT dan RW serta Kadus. Permasalahan diselesaikan dalam tiga tahapan kegiatan yaitu persiapan, pelaksanaan, dan evaluasi. Persiapan dilakukan dengan melakukan survey pendahuluan untuk melihat kondisi di lapangan mengenai rencana pengembangan layanan berbasis teknologi informasi dan komputer. Pelaksanaan dilakukan dengan pembenahan teknologi perangkat keras dan lunak disertai dengan pelatihan, dilanjutkan dengan diskusi tanya jawab dan latihan sebagai bentuk kegiatan simulasi untuk seluruh pelayanan yang disediakan oleh Kantor Desa. Evaluasi kegiatan dilakukan untuk masing-masing tahap dengan mengumpulkan dan menyimpulkan data dari masing-masing tahapan kegiatan. Setelah evaluasi, dilanjutkan implementasi pelaksanaan sistem langsung berinteraksi dengan masyarakat. Dalam periode tertentu dilaksanakan evaluasi untuk melakukan perbaikan secara berkelanjutan. Hasil kegiatan pelatihan menunjukkan keberhasilan dengan indikasi adanya peningkatan kepuasaan dari internal maupun masyarakat.
\end{abstract}

Kata kunci: e-desa; peningkatan; aparatur; profesional

\begin{abstract}
The importance of quality for village employees in the implementation of services and development from the results of the study showed that mental attitude factors, discipline factors, education factors in the field of service will be also determine the implementation of tasks for each village government employee. Community service aims to improve the quality of employees and the mastery of technology and information devices at the Village Office staff at Rimba Makmur. Providing insight knowledge about the importance of increasing professionalism in providing services to technology-based society. The target service is all employees, followed by all RT and RW and Kadus. The problem was resolved in three stages of activities namely preparation, implementation and evaluation. Preparations were made by conducting a preliminary survey to see conditions in the field regarding plans to develop information technology and computer based services. The implementation is carried out with the improvement of hardware and software technology accompanied by training, followed by discussion of questions and answers and exercises as a form of simulation activities for all services provided by the Village Office. Evaluation of activities is carried out for each stage by collecting and concluding data from each stage of the activity. After the evaluation, the implementation of the implementation of the system directly interacts with the community. In a certain period an evaluation is carried out to make improvements continuously. The results of the training activities showed success with an indication of increased satisfaction from internal and community.
\end{abstract}

Keywords: e-desa; growth; public servant; professional

To cite this article: Nurjayadi, T. Nasution, Herwin, \& K. Andesa. 2019. Peningkatan profesionalitas layanan aparatur desa berbasis e-desa bagi pegawai kantor Desa Rimba Makmur. Unri Conference Series: Community Engagement 1: 456-465 https://doi.org/10.31258/unricsce.1.456-465

(C) 2019 Authors

Peer-review under responsibility of the organizing committee of Seminar Nasional Pemberdayaan Masyarakat 2019 


\section{PENDAHULUAN}

Administrasi Desa, melakukan layanan administrasi warga Desa Rimba Makmur dan pada saat ini telah berjalan. Pengelolaan surat berhubungan dengan perizinan, keterangan, pernyataan, dan demografi kependudukan telah dilaksanakan sesuai dengan ketentuan yang berlaku. Seluruh tata laksana administrasi desa diselenggarakan secara manual. Pemerintahan desa berharap untuk dapat meningkatkan kualitas dan kuantitas layanan dengan kondisi sebaran geografis pemukiman seluas 560 Hektare. Jarak dari Kantor Kepala Desa Rimba Makmur berdasarkan mata angin, adalah (1) sebelah Utara jarak terjauh batas pemukiman adalah kaplingan lahan sawit masyarakat; (2) sebelah Timur jarak terjauh batas pemukiman adalah perkebunan PTPN V; (3) sebelah Selatan jarak terjauh batas pemukiman adalah PT. SIS Jati Langgak; (4) sebelah Barat jarak terjauh batas pemukiman adalah perkebunan PTPN V

Secara struktur Kepala Desa membawahi Kepala Dusun dan Sekretaris Desa. Desa Rimba Makmur terdiri atas 4 Kepala Dusun yang membawahi Rukun Warga dan Rukun Tetangga. Dalam pengelolaan administrasi desa Sekretaris Desa membawahi Kaur Pemerintahan, Kaur Umum, Kaur Keuangan, dan Kaur Pembangunan. Dalam menyelenggarakan administrasi pada Dusun maupun di Kantor Desa seluruhnya dilaksanakan secara manual, sekalipun sudah tersedia komputer, namun masih difungsikan sebagai pengganti mesin ketik.

Masyarakat berinteraksi secara langsung dengan pegawai kantor desa, dalam mengurus kelengkapan administrasi. Interaksi secara langsung, dengan suasana informal, turut mendukung iklim yang kondusif dalam menciptakan keharmonisan antara masyarakat staf desa. Posisi Kantor Desa berada di sisi Utara desa menyebabkan jarak tempuh dari sisi Selatan desa jarak tempuh sangat jauh. Media yang digunakan dalam perekaman data warga, baik layanan yang dibutuhkan, maupun kelengkapan surat keterangan masih dicatat dalam lembar buku agenda, hal ini ditunjukkan oleh Gambar 1. Implementasi pemanfaatan teknologi dalam memberikan layanan kepada masyarakat masih belum ada.

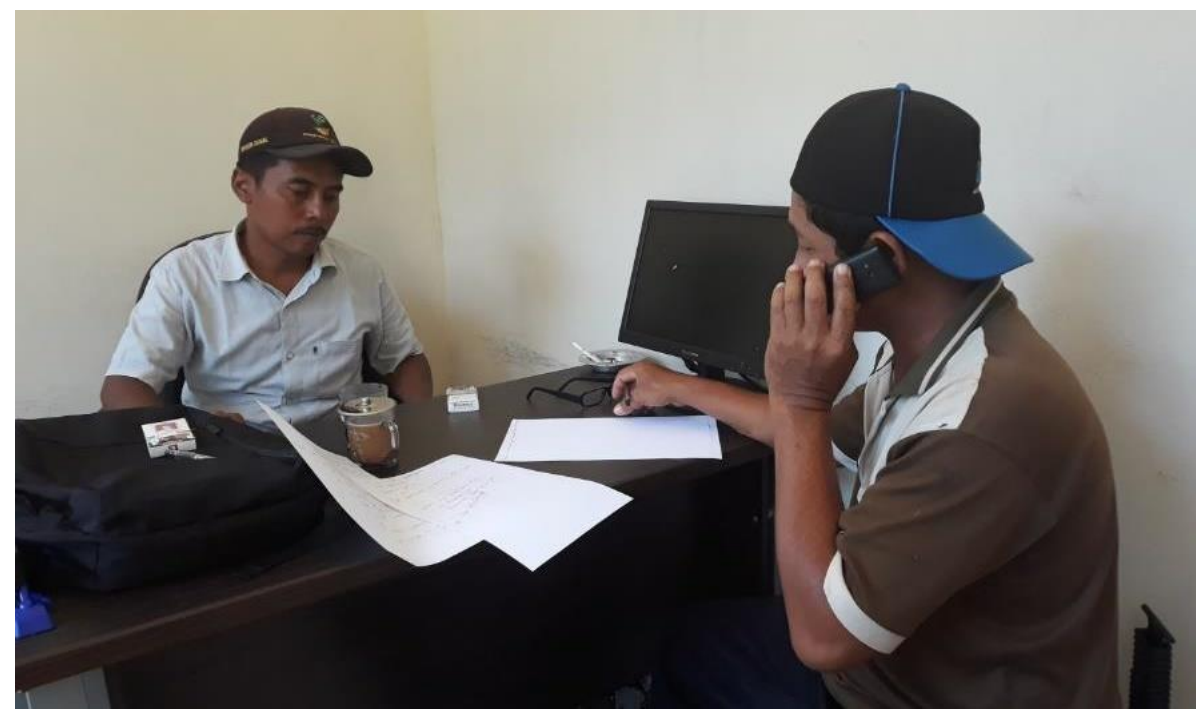

Gambar 1. Pegawai desa melayani administrasi masyarakat

Kantor desa telah menyediakan komputer desktop sebagai upaya implementasi teknologi, namun pegawai tidak selalu menggunakan dalam memberikan pelayanan. Justru lebih memilih menggunakan kertas sebagai media pembuatan surat menyurat, sebagaimana ditunjukkan pada gambar 8. Berdasarkan wawancara dengan Pak Suwanto (Kaur Pemerintah, pegawai yang sedang bertugas), menyampaikan bahwa komputer yang tersedia turut membantu pekerjaannya, namun kendala yang dialami adalah: (1) Komputer yang tersedia tidak praktis, dalam ukuran, daya yang digunakan, dan waktu yang dibutuhkan untuk menggunakan; (2) Data masyarakat tersedia dalam komputer, bilamana akan membutuhkan data tersebut, harus datang ke kantor dan mengaktifkan komputer; (3) Sampai saat ini, daya listrik yang tersedia belum stabil sepenuhnya, hal ini dibuktikan komputer yang tersedia sering mengalami kerusakan karena faktor listrik; (4) Asupan daya relatif lebih besar, walaupun monitor telah diganti menjadi LCD, hal ini turut mempengaruhi kenaikan biaya beban pemakaian listrik. 


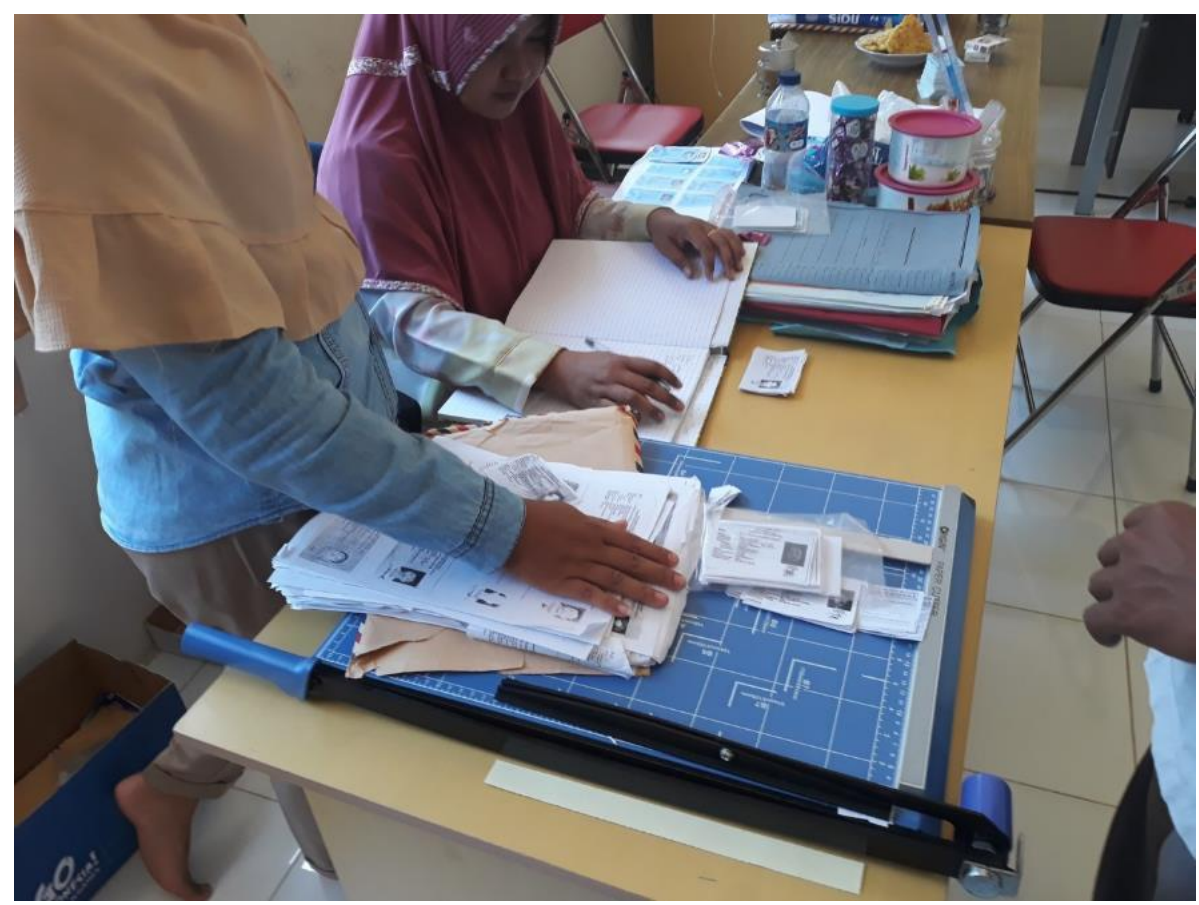

Gambar 2. Pemanfaatan Komputer di Kantor Desa Rimba Makmur.

Salah seorang pegawai dalam menyelesaikan pekerjaan memanfaatkan komputer sebagai media menyelenggarakan administrasi. Pegawai yang ada pada gambar 9. adalah Ibu Indri Astuti menjabat Kaur Keuangan Desa Rimba Makmur, menyampaikan bahwa dalam pengelolaan keuangan, komputer yang tersedia sudah membantu, namun masih terasa kelemahan, manakala daya listrik tidak stabil, menempati ruang relatif besar, otomatisasi, penyimpanan tidak portable, dan gangguan kerusakan. Harapan yang disampaikan adalah: tersedianya peralatan dengan daya rendah, memudahkan portabilitas data, dan sistem aplikasi kependudukan dan otomatisasi keuangan.

Tujuan kegiatan ini adalah membantu program pemerintah dalam pembangunan masyarakat dan wilayah desa, mensukseskan terlaksananya program RPJM Desa, mempercepat pembangunan desa pada berbagai bidang secara berkelanjutan, memperkuat sinergisme perguruan tinggi (PT) dengan stakehoder terkait dalam pembangunan desa. Target yang dicapai diterapkannya sistem pengelolaan desa berbasis elektronik.

Indikator peningkatan profesionalitas aparatur penyelenggara pemerintahan desa dapat diketahui (Nirmala A. Sahi, 2018) melalui aktifitas kearsipan atau penyimpanan dokumen yang tidak efektif, bahkan cenderung gagal dilaksanakan sebagaimana mestinya. Maksudnya adalah bahwa arsip-arsip surat-menyurat yang harusnya disusun dan tersimpan pada kantor tetapi hal itu tidak dilakukan. Akan tetapi dokumen/arsip SuratSurat dimaksud tidak disimpan rapi, sehingga sangat sulit untuk menemukannya kembali bila dibutuhkan. Perlu upaya pemberdayaan kelompok mitra (Aos Kuswandi, 2018) melalui penerapan teknologi infomrasi dan komputer dengan membangun pengelolaan administrasi degan berbasi elektornik. Mitra diberdayakan dengan membangun aplikasi pengelolaan administrasi desa. Dalam aplikasinya apa yang sudah dilatihkan kepada peserta pelatihan e-desa dapat bermanfaat bagi aktivitas pemerintahan dan masyarakat di desa peserta pelatihan. Hal ini cukup menggembirakan dan dapat ditindaklanjuti dalam pendampingan dan pembinaan agar berkelanjutan. Tim fasilitator, lembaga perguruan tinggi, mahasiswa, pemerintah desa dan masyarakat perlu menjalin kerjasama untuk pemanfaatan e-desa selanjutnya. Dengan demikian dapat dijamin keberlanjutan edesa di pemerintahan desa Rimba Makmur Kecamatan Tapung Hulu Kabupaten Kampar Provinsi Riau. Masih terdapat (Sitti Aminah dkk, 2018) kesenjangan pengetahuan antara kepala desa dan Sekdes di satu sisi dan bendahara desa di sisi lain. Hal ini dikarenakan Kepala Desa dan Sekdes memiliki kapasitas manajerial pengelolaan pemerintahan desa lebih baik dibandingkan bendahara desa. Bendahara desa lebih menguasai teknis pengelolaan keuangan desa dan kurang menguasai aspek pengelolaan pemerintahan desa secara keseluruhan. Sebagai upaya mendapatkan hasil yang optimal diperlukan pendekatan (Hernawan Sulistyanto, 2017) individual dan klasikal. Pendekatan klasikal dilaksanakan pada saat pemberian dan penyampaian materi mengenai pengetahuan umum komputer dan aplikasinya. Sedangkan pendekatan individual dilakukan pada saat latihan dan tanya-jawab. 


\section{METODE PENERAPAN}

Metode pelaksanaan kegiatan Pelatihan ini dilakukan di Desa Rimba Makmur dengan diagram dibawah ini.

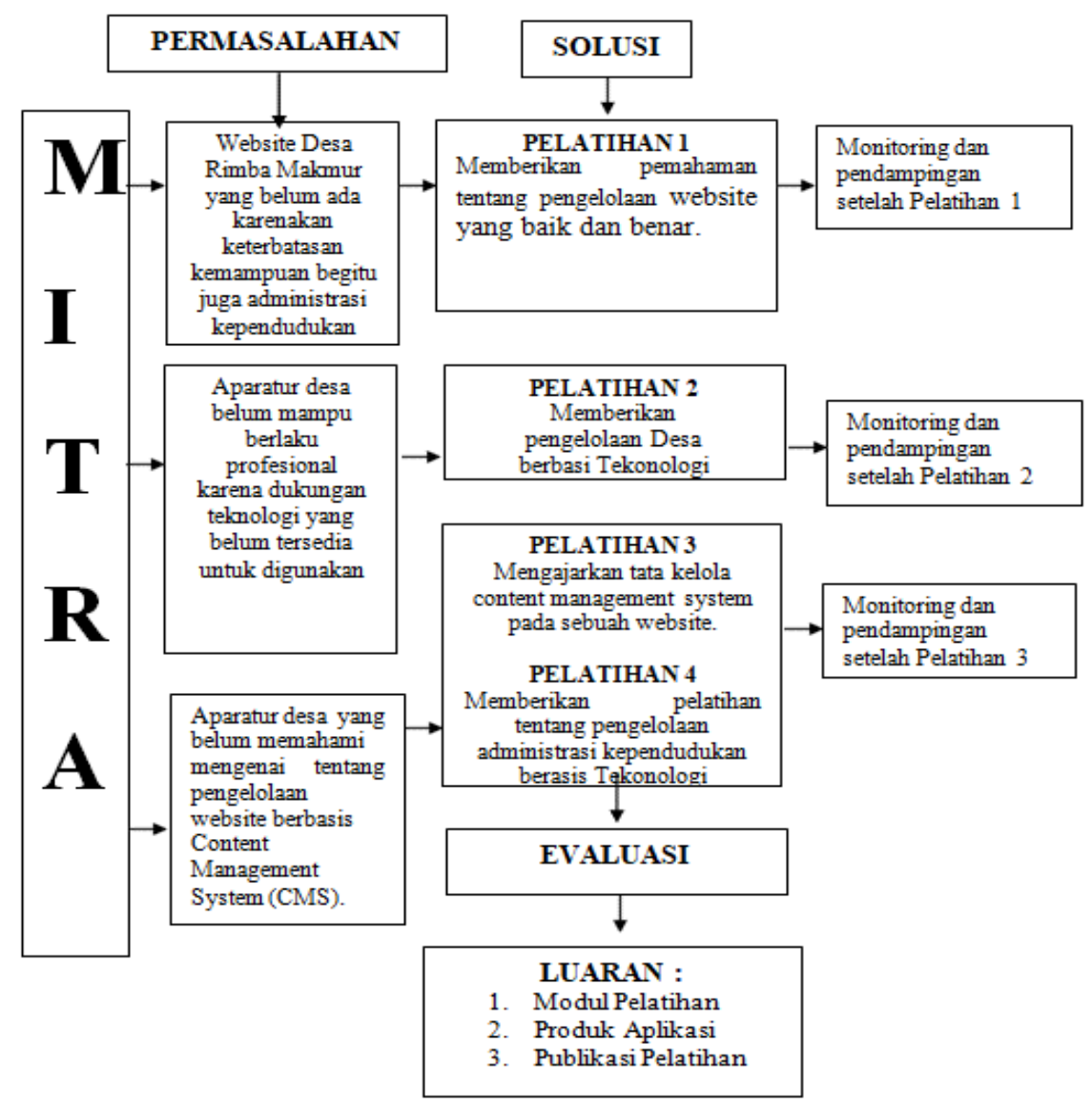

Gambar 3. Metode Pelaksanaan

\section{Road Map Pengabdian}

Pengabdian ini merupakan bagian dari pengabdian pengembangan desa mitra yang telah dilakukan para narasumber/dosen bersama tim di Desa Rimba Makmur, fokus penganbdian yang dilakukan adalah tentang peningkatan profesionalitas layanan aparatur elektronik bagi pegawai. Berikut pada Tabel 1 roadmap kerja yang telah dilakukan oleh para narasumber (dosen) bersama tim.

Tabel 1. Roadmap kerja

\begin{tabular}{|c|c|c|c|}
\hline No & Waku Kegiatan & Uraian kegiatan & Hasil \\
\hline 1 & $1 / 4 / 2019$ & $\begin{array}{l}\text { Upaya peningkatan layanan oleh aparatur } \\
\text { desa berbasis Internet }\end{array}$ & $\begin{array}{l}\text { Disetujui rancnagan pembuatan halaman } \\
\text { website }\end{array}$ \\
\hline 2 & 29/4/2019 & $\begin{array}{l}\text { Launching Website Desa } \\
\text { www.rimbamakmur.desa.id dan } \\
\text { penggunaan bagi masyarakat }\end{array}$ & Tersedia domain yang akan digunakan \\
\hline 3 & $2 / 5 / 2019$ & $\begin{array}{l}\text { Pelatiahan Pembuatan Website DesaBagi } \\
\text { Aparatur Desa Rimba Makmur }\end{array}$ & $\begin{array}{l}\text { Kemampuan dan pemahaman dalam } \\
\text { pembuatan halaman web site serta } \\
\text { penggunaan }\end{array}$ \\
\hline 4 & $2 / 5 / 2019$ & $\begin{array}{l}\text { Pelatiahan Pembuatan Aplikasi } \\
\text { Kependudukan Bagi Admin Desa Rimba } \\
\text { Makmur }\end{array}$ & $\begin{array}{l}\text { Kemampuan mengoperasikan halaman } \\
\text { website kependudukan }\end{array}$ \\
\hline 5 & $2 / 5 / 2019$ & Pelatihan tenaga administrasi & $\begin{array}{l}\text { Kemampuan tenaga administrasi dalam } \\
\text { memberikan layanan kepada masyarakat }\end{array}$ \\
\hline
\end{tabular}




\begin{tabular}{|c|c|c|c|}
\hline No & Waku Kegiatan & Uraian kegiatan & Hasil \\
\hline 6 & $1 / 6 / 2019$ & Pembuatan Domain & $\begin{array}{l}\text { Tersedia domain } \\
\text { http://www.rimbamakmur.desa.id }\end{array}$ \\
\hline 7 & 6/7/2019 & $\begin{array}{l}\text { Pelatiahan Entry Data Website Bagi } \\
\text { Administrator Desa Rimba Makmur }\end{array}$ & $\begin{array}{l}\text { Kemampuan administrator dalam } \\
\text { mengelola halaman website }\end{array}$ \\
\hline 8 & 6/7/2019 & $\begin{array}{l}\text { Pelatiahan modul Data Kependudukan Bagi } \\
\text { Aparatur Desa Rimba Makmur }\end{array}$ & $\begin{array}{l}\text { Kemampuan aparatur desa dalam } \\
\text { melakukan pembaharuan terhadap data } \\
\text { kependudukan }\end{array}$ \\
\hline 9 & $6 / 7 / 2019$ & Pelatihan Helpdesk bagi tenaga teknis & $\begin{array}{l}\text { Kemampuan dalam melakukan handling } \\
\text { permasalahan dan sistem penangangan }\end{array}$ \\
\hline
\end{tabular}

\section{HASIL DAN KETERCAPAIAN SASARAN}

Tidak ada teori atau teknik khusus yang bisa membuat seseorang menjadi profesional dalam memberikan layanan terhadap masyarakat. Ketersediaan sistem yang menjadi pendukung serta kemampuan seseorang bersikap dan berbuat secara profesional dalam memberikan layanan menjadi kunci utama dalam memberikan layanan kepada masyarakat. Selain itu, profesional di peroleh bilamana seseorang memiliki pengetahuan yang cukup, dilakukan dengan cara meningkatkan literasi buku, majalah, surat kabar dan meyimak berita di televisi atau radio. Menurut Soempomo Djojowadono (1987), merumuskan professional adalah (1) mempunyai sistem pengetahuan yang isoterik (tidak dimiliki sembarang orang); (2) ada pendidikannya dan latihannya yang formal dan ketat; (3) membentuk asosiasi perwakilannya; (4) ada pengembangan Kode Etik yang mengarahkan perilaku para anggotanya; (5) Pelayanan masyarakat/kemanusian dijadikan motif yang dominan; (6) otonomi yang cukup dalam mempraktekkannya; (7) penetapan kriteria dan syarat-syarat bagi yang akan memasuki profesi.

Seorang profesional harus mempunyai keahlian yang di dapatkan melalui suatu proses pendidikan dan disamping itu terdapat unsur semangat pengambilan dalam melaksanakan suatu kegiatan kerja. Dalam melakukan tugas profesi, seorang profesional harus dapat bertindak objektif dalam memberikan layanan kepemerintahan terhadap masyarakat, yang artinya bebas dari rasa sentimen, benci, malu maupun rasa malas dan enggan bertindak serta mengambil keputusan. Seorang aparatur desa yang menyatakan diri profesional, hendaklah memiliki tiga hal pokok yang ada didalam dirinya, yang diantaranya meliputi:

1. Skill, yang artinya orang tersebut harus benar-benar ahli di bidangnya.

2. Knowledge, yang artinya orang tersebut harus dapat menguasai, minimalnya berwawasan mengenai ilmu lain yang berkaitan dengan bidangnya.

3. Attitude, yang artinya bukan hanya pintar, akan tapi harus memiliki etika yang diterapkan didalam bidangnya.

Adapun ciri ciri dari profesional yang diantaranya sebagaimana di bagian bawah ini:

1. Memiliki kemampuan dan pengetahuan yang tinggi.

2. Memiliki kode etik.

3. Memiliki tanggung jawab profesi serta integritas yang tinggi.

4. Memiliki jiwa pengabdian kepada masyarakat.

5. Memiliki kemampuan yang baik dalam perencanaan program kerja.

6. Menjadi anggota organisasi dari profesinya.

Dalam pengabdian mitra desa, ada beberapa materi yang disampaikan, khususnya dalam peningkatan profesionalitas aparatur desa dalam memberikaln layanan berbasis teknologi.

\section{Struktur e-Desa}

Dalam memberikan pelayanan berbasis teknologi, ada kerangka sebagai pegangan yang memudahkan aparatur untuk memberikan layanan administrasi desa kepada masyarakat. Kemampuan memberikan pelayanan sesuai dengan standar yang telah ditetapkan merupakan acuan utama dalam mengukur tingkat profesionalitas. Halaman website yang telah disediakan, terdiri atas:

1. Portal berita, memuat halaman statis yang dikelola melalui content management system. Dalam pengoperasian, di rancangan dan dibuat semudah-mudah untuk mempercepat dan menurunkan potensi kesalahan oleh operator.

2. Administrasi kependudukan, menyediakan pengelolaan data yang melibatkan masyarakat secara langsung dan aparatur desa sesuai dengan tugas pokok dan fungsinya. 
Hasil kegiatan yang diselenggarakan oleh Kantor Desa, disebarkan melalui pemuatan pada portal berita, yang terdiri atas:

1. Informasi, memuat berita terbaru berhubungan dengan kegiatan yang diselenggarakan maupun kejadian yang dialami oleh desa

2. Profil Desa, memuat sejarah desa, visi dan misi, kata Pengantar oleh Kepala Desa

3. Lembaga, memuat organsiasi yang berada dalam naungan desa, yang terdiri atas Karang Teruan, BPD, LPMD, RT/RW, BUMDES, Perpustakaan Desa, BAZ, PKK, Kelomok Tani, dan LINMAS

4. Layanan, memuat Penerbitan KK, Pembuatan KK, Pembuatan Akta, Pembuatan PKH, Jamkesda

5. Transparansi Desa, memuat transparansi anggaran, dan rencana kerja dan anggaran

6. Regulasi, memuat peraturan, edaran, dan panduan yang dikeluarkan oleh desa

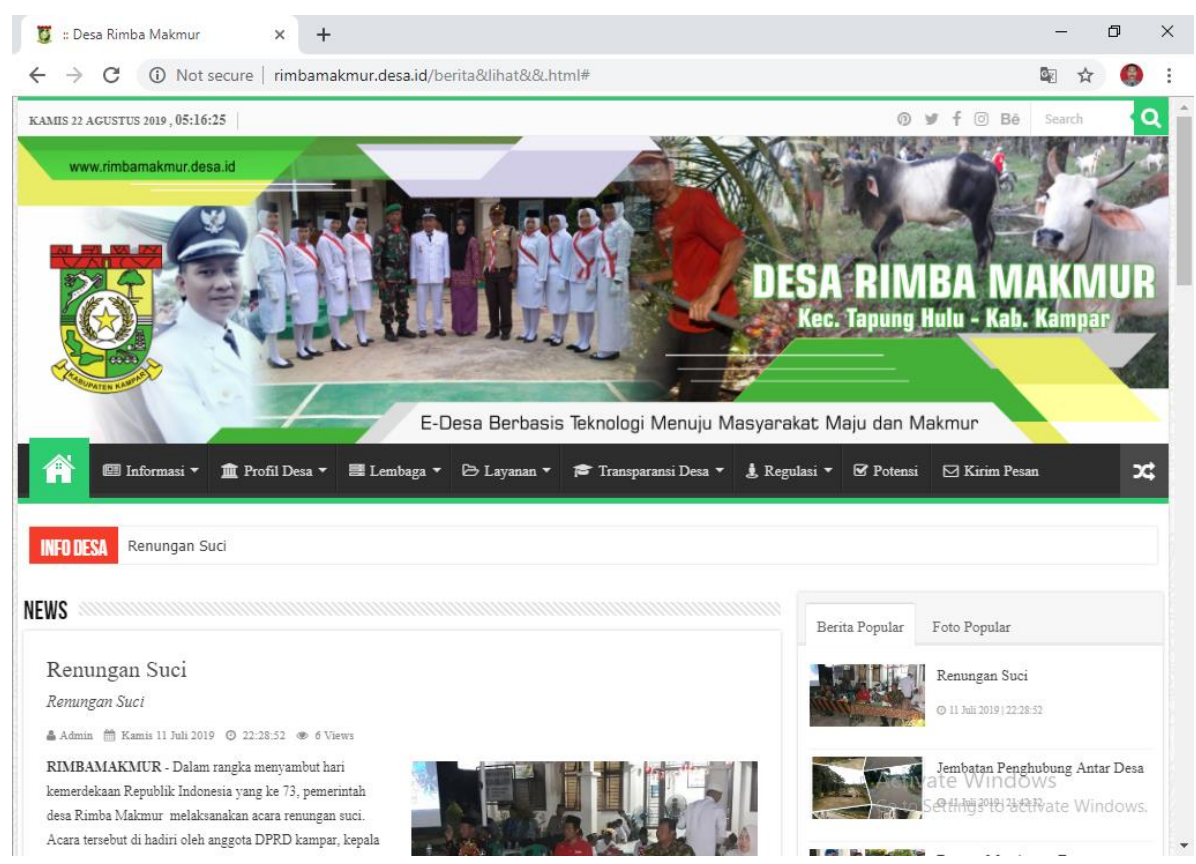

Gambar 4. Halaman utama web desa

Interaksi antara masyarakat dengan RT, RW, Kepala Dusun, maupun aparatur desa dapat dilakukan melalui Administrasi Kependudukun. Bentuk halaman adalah:

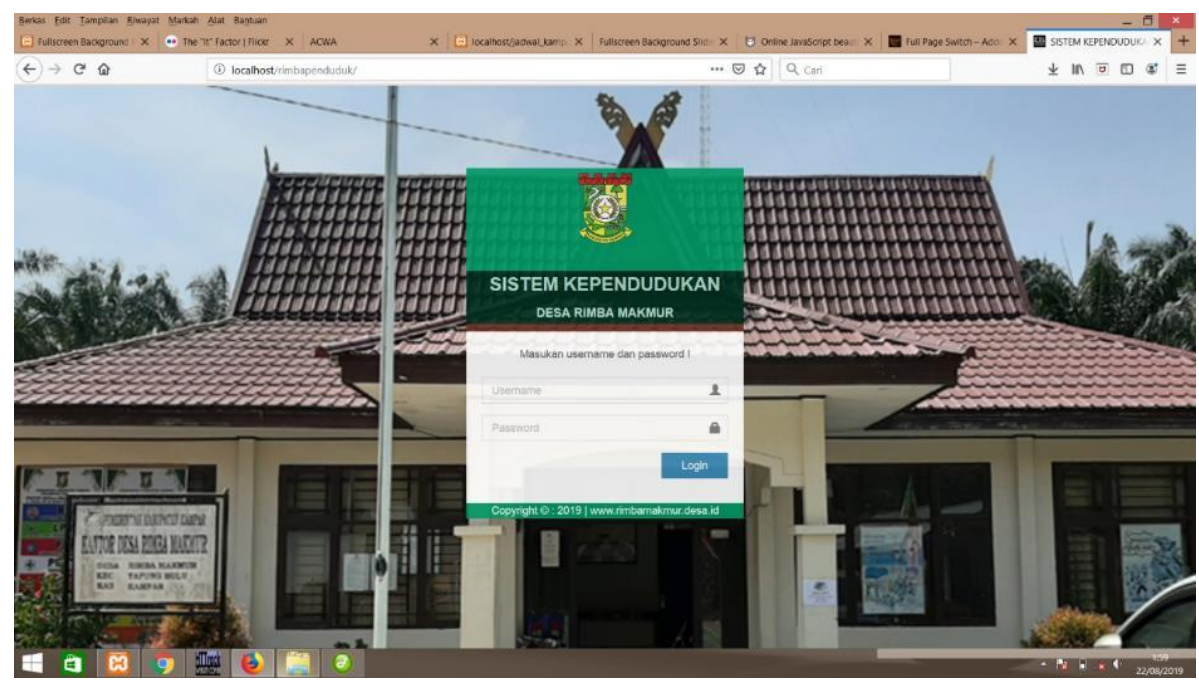

Gambar 5. Halaman Login Administrasi Kependudukan 


\section{Hasil Pengabdian}

Gambar 3 tersebut merupakan, hasil dari pengabdian yang telah dilakukan. Organisasi Adijaya telah memiliki website desa, dengan alamat www.rimbamakmur.desa.id.

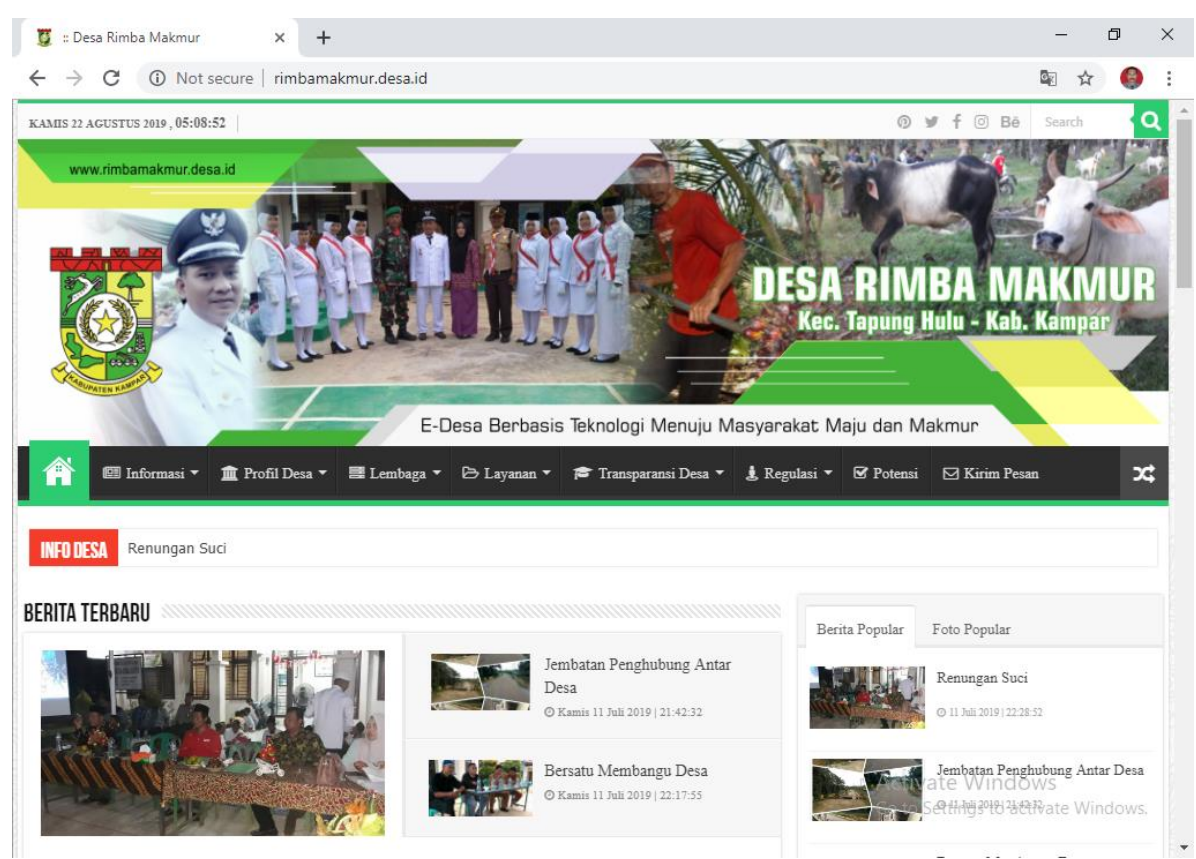

Gambar 6. Halaman login untuk masuk ke dalam sistem Administrasi Kependudukan

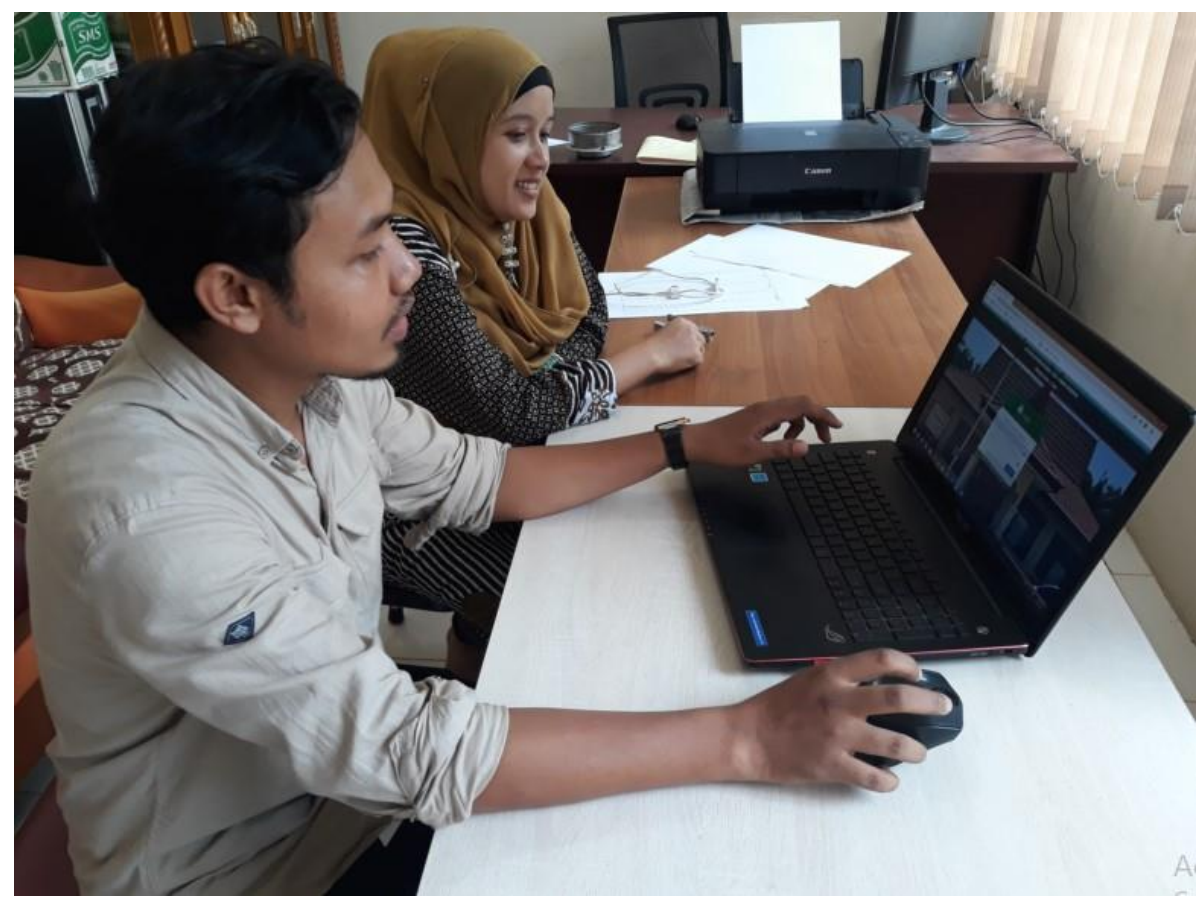

Gambar 7. Seorang pengabdi melakukan pendampingan terhadap aparatur desa 


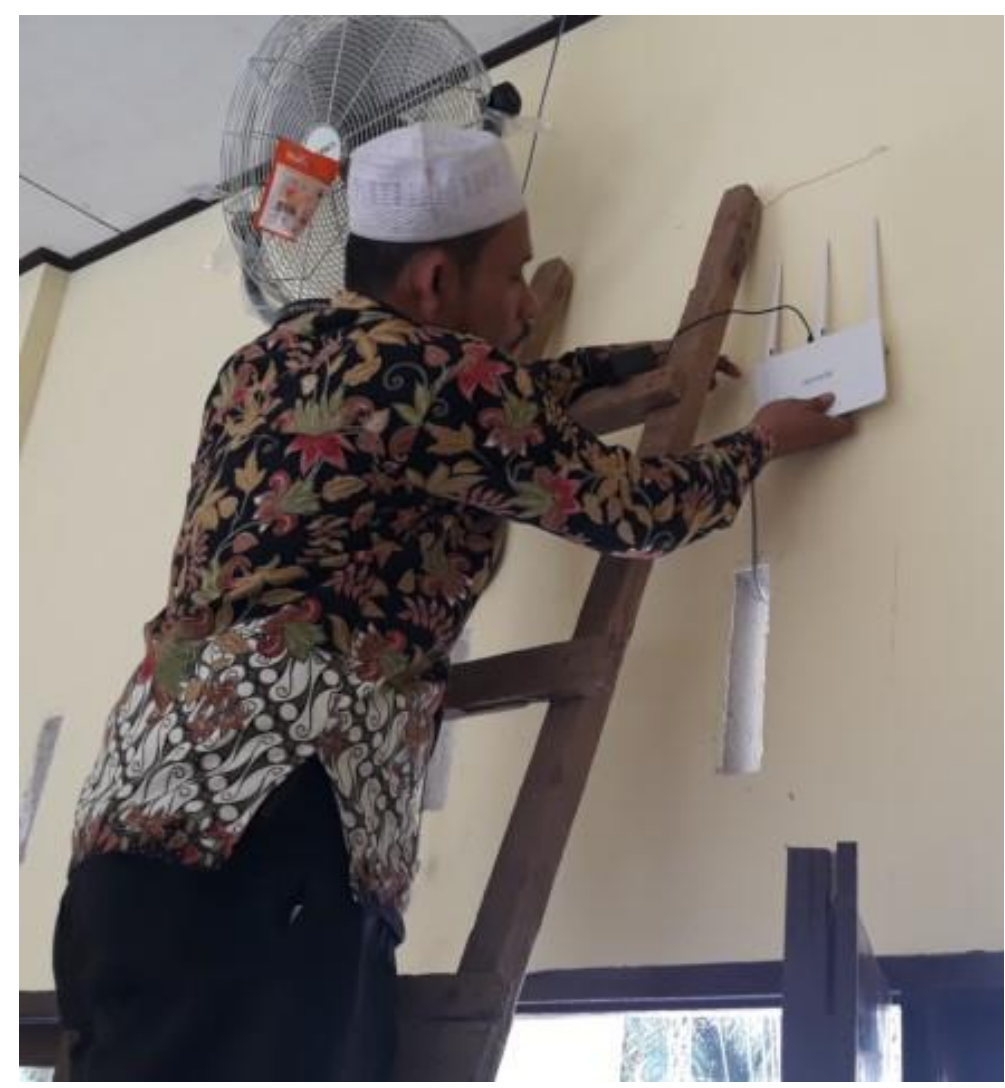

Gambar 8. pemasangan akses point untuk perluasan jangkauan layanan

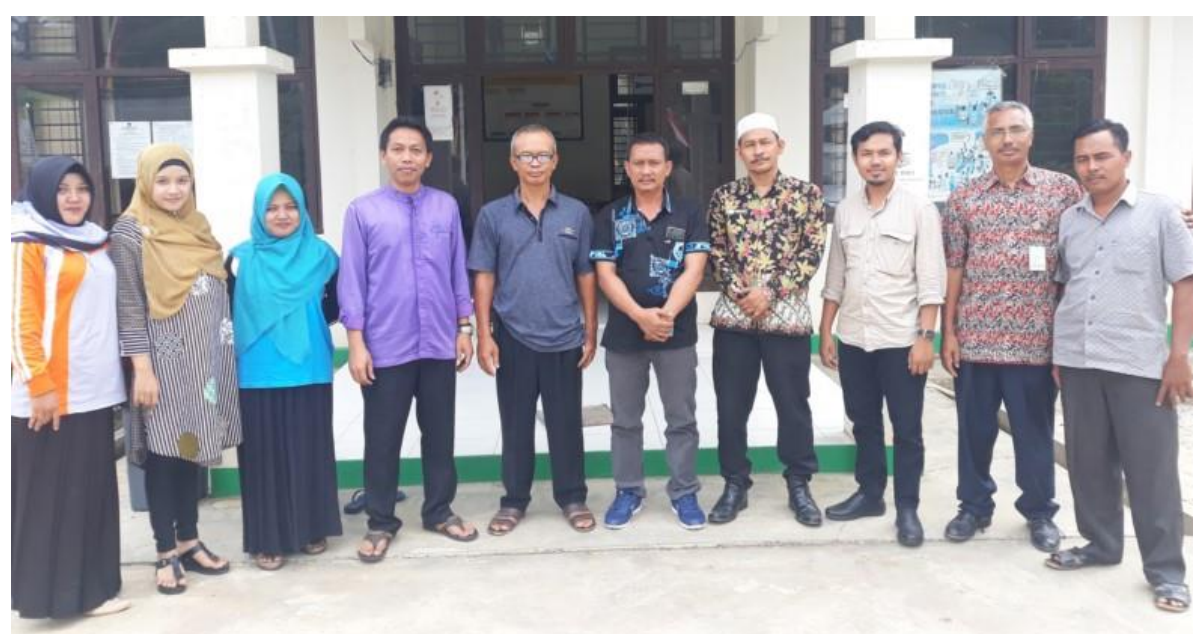

Gambar 9. Foto bersama Kepala Desa dan aparatur Desa Rimba Makmur 


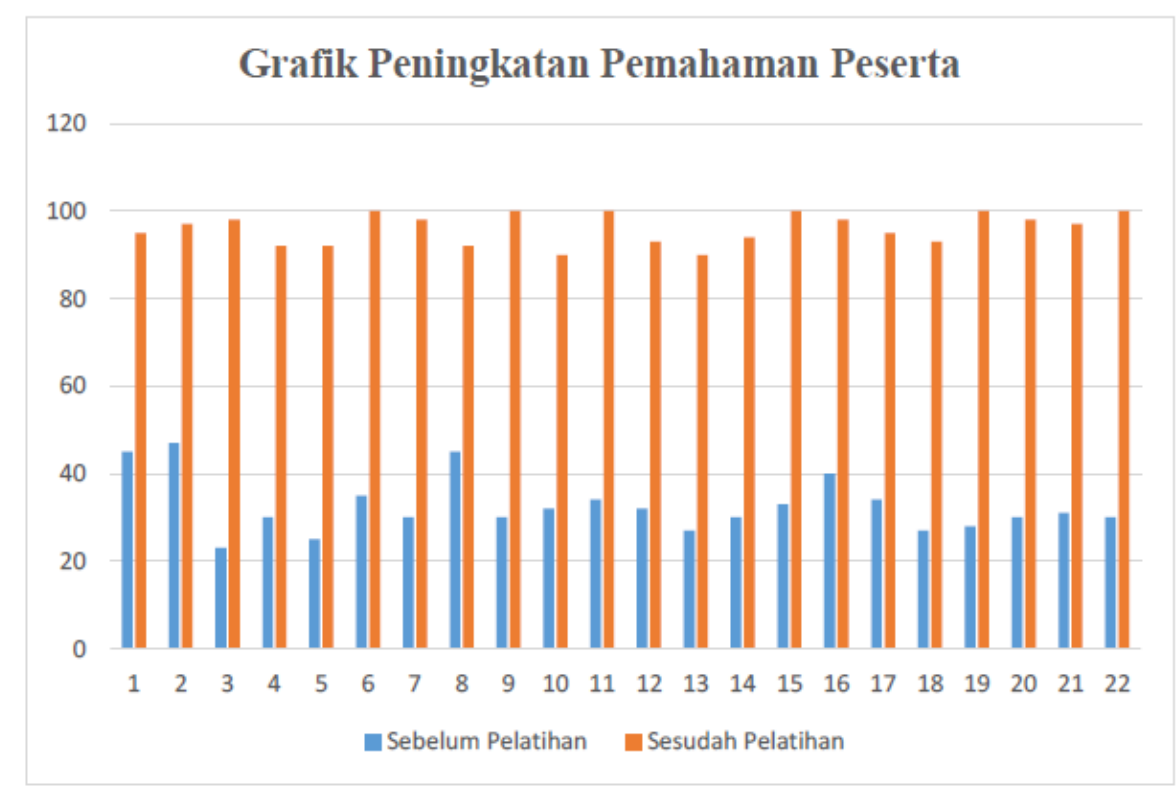

Gambar 10. Grafik Pemahaman Materi oleh Peserta

\section{Pendampingan Pasca Pengabdian}

Setelah diadakannya pelatihan dan implementasi administrasi desa berbasis teknologi tentu akan ditemukan kendalam dan perlu peningkatkan pemahaman serta kemampuan. Oleh karenanya, tim pengabdian membuat komunitas Grup Whatsappp untuk mengantisipasi kendala yang dialami peserta pasca pelatihan.

\section{KESIMPULAN}

Berdasarkan pelaksanaan pengabdian yang telah dilakukan, terdapat beberapa kesimpulan yang diperoleh yaitu:

1. Masyarakat Rimba Makmur telah 'bermigrasi' sebagai desa global village dengan mamnfaatkan internet sebagai langkah awal dalam memberikan informasi kepada masyarakat dengan memiliki website www.rimbamakmur.desa.id.

2. Masyarakat Rimba Makmur, telah memiliki kemampuan ketrampilan dalam mengoperasionalkan website untuk memberikan layanan kepada masyarakat.

3. Masyarakat Rimba Makmur, telah memiliki kemampuan dalam berinteraksi untuk kebutuhan administrasi kependudukan serta sumber berita melalui portal www.rimbamakmur.desa.id milik desa

Diperlukan pengembangan lanjutan dalam peningkatan profesional aparatur desa untuk mencapai:

1. Pelaksanaan pengabdian dengan fokus pembuatan website di Desa Rimba Makmur, perlu dilanjutkan kepada desa-desa yang lain untuk mengembangkan potensi desa yang ada.

2. Pendampingan kepada desa harus terus dilakukan secara berkelajutan terutama pada pemberian layanan terhadap masyarakat berhubungan administrasi kependudukan, pemasukan berita, maupun pengambangan pada website desa.

\section{UCAPAN TERIMA KASIH}

Penulis mengucapkan terima kasih kepada Lembaga Penelitian dan Pengabdian Masyarakat STMIK Amik Riau dan Kemenristekdiktiyang telah membantu dalam pelaksanaan program pengabdian masyarakat ini. Dan terimakasih kepada Pihak Desa Rimba Makmur yang sudah membantu amalsoleh pelaksanaan kegiatan ini. 


\section{DAFTAR PUSTAKA}

Aos, K., K. Dewi, \& K. Nia. 2018. Pelatihan e-government bagi aparat pemerintah desa di Kecamatan Ciampel Kabupaten Karawang. Jurnal Abdimas Mandiri 2(1).

Fitri, T. A., N. Torkis, \& Herwin. 2015. Pengembangan Model Pelayanan Kantor Desa terhadap Masyarakat Berbasis Mobile Computing. Jurnal Edukasi dan Penelitian Informatika (JEPIN) 1(2).

Hernawan, S. 2017. Pakom Pelatihan Pengoperasian Komputer bagi Perangkat Desa di Kecamatan Gondangrejo Kabupaten Karanganyar. p ISSN: 1410-9344, e ISSN: 2549-5631. Warta LPM 20(2): 111-114.

Putu, E. D. M. D., A. K. S. Komang, A. P. Made. 2017. Hubungan Kualitas Pengelolaan Aset Desa dan Pendapatan Asli Desa (Studi pada Desa-desa di Kabupaten Buleleng - Bali). Seminar Nasional Riset Inovatif 2017. Senari 2017.

Sitti, A., P. S. Hari. 2018. Analisa Tingka Kapasitas Aparatur Pemerintah Desa di Kabupaten Bogor. Matra Pembaruan 2(3): $149-160$. 